
\title{
HORSE \\ GENEALOGICAL STRUCTURE OF NOVOALEXANDROVSKY DRAFT
}

Pavlovsky S. S., Tkachova I. V., Institute of animal science NAAN.

The aim of the work was to analyze the condition of the breed horses in Ukraine and assess its genealogical structure. The object of research was the results of the appraisal of horses, breed database in Institute of animal science NAAN, as well as the Studbook of breeding horses Novoalexandrovsky Draft horses (1, 2 volumes).

To determine the genealogical structure of the breed, the entire reproductive composition was distributed, along genealogical lines, mare families and stud nests. As a result groups of mares with a common ancestor, no less than two branches and three generations of descendants were assigned to new mare families. Groups of mares with a common ancestor, not less than with two branches and two generations of descendants are referred to new stud nests.

It is established that the number of horses of the Novoalexandrovsky Draft horse steadily decreases with each decade years. Analysis genealogical structure showed, that the most the spread of in breed among stallions-producers received genealogical lines: (1390) Tantal (32,0 \%), (935) Koketlivyj (44,0\%), (909) Gradus (8,0\%). The distribution of the breeding stock on lines: most mares belong to the lines of (1390), Tantal (22.9\%), (935) Koketlivy (17.6\%), (909) Gradus (17.6\%), as well as (200) Kapiten (16.9\%) and (109) Gazon (9.5\%).

The study revealed 307 representatives of 13 old mare families and 94 representatives of 6 new breeding families and 4 stud nests. The most common mare family of Tunguska (19,6\%). Of the new mare families - Lava (8.1\%).

Thus, to maintain heterozygosity breeds of horses with a limited gene pool, it is necessary to maintain extensive genealogical structure. It is planned to continue the work on selection and selection evaluation of new genealogical branches and registration of them as independent breeding families and nests, to include the tasks of their formation and improvement in the new breeding program.

Keywords: horses, Novoaleksandrovskaya Draft horse, male lines, mare's families, body measurements, body structure indices, reproductive function.

DOI 10.32900/2312-8402-2019-122-138-146

УДК 636.934.2.082:575

\section{ОЦІНКА ГЕНЕТИЧНОЇ МІНЛИВОСТІ ГРУПИ ЛИСИЦЬ ЗА ДНК-МАРКЕРАМИ ISSR I RAPD}

\author{
Петраш В. С., H. с., \\ Корх О. В., К. с.-Г. Н., с. Н. с, \\ Kорх I. В., К. с.-Г. Н., с. Н. c, \\ Шуліка Л. В., М. н. с. \\ Інститут тваринництва НААН
}

Сучасні світові наукові досягнення в області молекулярної генетики зосередили увагу дослідників на нових методах $i$ підходах щцодо генетичних досліджень, які базуються на безпосередньому аналізі ДНК, як основи спадковості та мінливості тварин, у тому числі й тих, щуо мають сільськогосподарську цінність. Серед хутрових звірів, яких утримують в неволі, лисиия звичайна та сріблясточорна лисиия, як ї̈ меланістична форма, є одними з перспективних об'єктів ви- 
вчення за допомогою молекулярно-генетичних методів. На сьогодні в літературі накопичено значну частину експериментальних даних, що розкривають сутність та широке використання ДНК-маркерів для очінки генетичного різноманіття різних сільськогосподарських тварин. Натомість у хутровому звірівнищтві такі дослідження розпочали реалізовуватись, порівняно з іншими галузями твариннииттва, не так давно, а щзодо оцінки поліморфізму ДНК - наявні лише поодинокі повідомлення.

В рамках проведених досліджень проаналізовано 54 голови лисищь від яких були відібрані зразки біологічного матеріалу (шматочки шкіри з хутром) й одержано спектри ампліфікаційних фрагментів за двома маркерами ISSR (ISSR1 $i$ ISSR2) ma wicmь - RAPD (OPG-04, OPG-07, OPG-17, M-9, M-15, OPE-4). Аналіз одержаних результатів дав змогу виявити значний поліморфізм кожного з використаних ISSR-маркерів у піддослідній групі лисищь. У кожному випадку (зразку) були наявні певні спектри ампліфікаційних фрагментів. Ампліфікаційні фрагменти за кожним з RAPD-маркерів, щзо використовували в дослідженні, характеризувалися різною кількістю та розмірами, а в переважній більшості проаналізованих зразків також були виявлені спещифічні спектри (набір локусів) майже для кожної особини піддослідної групи.

За використання полілокусних ДНК-маркерів встановлено високий рівень геномної варіабельності дослідної групи лисищь, щуо свідчить про достатній ступінь ї̈ популяційного біорізноманіття, незважаючи на те, щзо вона розводиться в межах замкненої популяиії $і$ не має ,,прилиття” крові.

Ключові слова: генетична мінливість, ДНК-маркери, локуси, поліморфізм, сріблясто-чорна лисиця, шматочки шкіри

Сучасні світові наукові досягнення в області молекулярної генетики зосередили увагу дослідників на нових методах і підходах щодо генетичних досліджень, які базуються на безпосередньому аналізі ДНК, як основи спадковості та мінливості тварин, у тому числі й тих, що мають сільськогосподарську цінність. Серед хутрових звірів, яких утримують в неволі, лисиця звичайна та сріблясточорна лисиця, як іï меланістична форма, є одними з перспективних об'єктів вивчення за допомогою молекулярно-генетичних методів.

Основним методом цих досліджень $є$ полімеразна ланцюгова реакція (ПЛР), на основі якої розроблено цілу низку молекулярно-генетичних або ДНКмаркерів, які в широкому сенсі представляють собою поліморфні фрагменти ДНК [1].

Серед ДНК-маркерів у генетичних дослідженнях зі сріблясто-чорною лисицею та іншими хутровими звірами застосовують як мультилокусні (RAPD, ISSR), так і монолокусні маркери (SSR, SSCP). Монолокусні маркери, на відміну від мультилокусних, мають відому локалізацію в геномі [2]. Разом із тим слід зазначити, що на сьогодні відомі й дослідження, в яких визначали поліморфізм не лише ядерної, але й мітохондріальної ДНК лисиці [3, 4].

RAPD - Random Amplified Polymorphic DNA, тобто довільно ампліфікаційна поліморфна ДНК [5]. RAPD-аналіз є простим та зручним, але йому властиві й недоліки, зокрема, він не дає змоги відрізнити гетерозигот від гомозигот, а також характеризується невисокою відтворюваністю в умовах різних лабораторій [6].

ISSR - Inter-Simple Sequence Repeat, як і RAPD, відносять до полілокусних маркерів домінантного типу. Завдяки більшій довжині праймерів метод має кращу відтворюваність, ніж RAPD [6]. 
Попри це обидва методи дають змогу оцінити загальну генетичну різноманітність тварин.

В останні роки пильну увагу науковців привертає питання оцінки генетичного базису доместикації лисиці та визначення особливостей іiї поведінки стосовно людини. В рамках тривалого вивчення двох унікальних популяцій сріблясточорних лисиць встановлено певні особливості стереотипу поведінки залежно від їх розподілу за агресивністю або дружелюбністю [8-10]. У різні роки авторами цих публікацій здійснено генетичне картування обох ліній, які пов'язані з тими чи іншими поведінковими патернами, виконано аналіз окремих елементів поведінки, секвеновано геном. Крім того їм вдалося виявили низку QTL, локалізованих у межах хромосом 12 і 14, та ідентифікували окремі гени, котрі відповідають за дружелюбну поведінку, серед яких мав місце ген SorCS1.

Водночас слід констатувати про фрагментарність вивчення генетичних ресурсів лисиці за допомогою ДНК-маркерів та зміщення напряму фахівців на аналіз природних популяцій.

Виходячи з цих передумов, оцінка внутрішньогрупової генетичної мінливості сріблясто-чорних лисиць за ДНК-маркерами ISSR i RAPD підкреслює незаперечне науково-практичне підгрунтя проблеми, визначає їі актуальність та є підставою для проведення поглибленого наукового пошуку.

Мета досліджень - оцінити внутрішньогрупову генетичну мінливість сріблясто-чорних лисиць за ДНК-маркерами ISSR i RAPD.

Матеріали та методика досліджень. Геномну ДНК виділяли зі зразків біологічного матеріалу сріблясто-чорних лисиць за допомогою набору „ДНК-Сорб B” (AmpliSens, Росія). Як біологічний матеріал використовували шматочки шкіри 3 хутром, одержані під час забою піддослідних звірів. Загалом проаналізували 54 зразки. Для оцінки генетичної мінливості групи лисиць застосовували два маркери ISSR (ISSR1 і ISSR2) та шість RAPD (OPG-04, OPG-07, OPG-17, M-9, M-15, OPE-4). Ампліфікацію проводили за використання наступних праймерів: ISSR1 $(\mathrm{AG})_{9} \mathrm{C}$; ISSR2 - (GA) ${ }_{9} \mathrm{C}$, OPG-04 - AGCGNGTCTG, OPG-07 - GAACCTGCGG, OPG-17 - ACGACCGACA, M-9 - CTCACCGTCC, M-15 - GACGGATCAG, OPE-4 - GTGACATGCC.

Ампліфікацію досліджених фрагментів здійснювали за допомогою термоциклера AMPLY 4 (Biocom, Росія). Для ISSR-маркерів використовували наступну програму: початкова денатурація - 2 хв за $94{ }^{\circ} \mathrm{C} ; 35$ циклів - денатурація 30 хв за $94{ }^{\circ} \mathrm{C}$, відпал 30 хв за $55^{\circ} \mathrm{C}$, елонгація 2 хв за $72{ }^{\circ} \mathrm{C}$; фінальна елонгація -10 хв за $72{ }^{\circ} \mathrm{C}$. Для RAPD-маркерів ампліфікацію виконували за такими параметрами: початкова денатурація - 5 хв за $95^{\circ} \mathrm{C} ; 45$ циклів - денатурація 1 хв за $95{ }^{\circ} \mathrm{C}$, відпал 1 хв за $35^{\circ} \mathrm{C}$, елонгація 2 хв за $72{ }^{\circ} \mathrm{C}$; фінальна елонгація - 10 хв за $72{ }^{\circ} \mathrm{C}$. Об'єм реакційної суміші становив 20 мкл, концентрація праймерів - 0,6 мкМ. Після ампліфікації проводили горизонтальний електрофорез в агарозному гелю (для ISSRмаркерів використовували концентрацію 2 \%, RAPD-маркерів - 1,7 \%) із додаванням барвника (бромистий етидій) за схемою: 40 хв/200 V, потім 60 хв/100 V. Визначення розмірів ампліфікаційних фрагментів виконували за допомогою маркера молекулярних мас Bme18 I (SibEnzyme, Росія) у середовищі програми Ge1Analyer2010. Для візуалізації та фіксації результату електрофорезу використовували УФ-трансілюмінатор і цифрову фотокамеру.

Оцінку генетичної мінливості дослідної групи сріблясто-чорних лисиць проводили за такими показниками: TNB (total number of bands) - загальна кількість виявлених локусів (окремих смуг на електрофореграмі $з$ певною молекулярною масою), NPB (number of polymorphic bands) - кількість виявлених поліморф- 
них локусів (що були виявлені лише у певної частини групи), $\mathrm{P} \%$ (procentage of polymorphic bands) - відсоток виявлених поліморфних локусів (NPB/TNB). Кожен iз параметрів вираховували для окремих маркерів та в середньому за кожним із типів маркерів. Для ISSR-маркерів оцінили розподіл числа локусів за їх молекулярною масою (до 500 п. н., від 500 до 1000 п. н., більші за 1000 п. н.).

Результати досліджень. У рамках виконаних досліджень одержано спектри ампліфікаційних фрагментів за двома маркерами ISSR (ISSR1 і ISSR2) та шість - RAPD (OPG-04, OPG-07, OPG-17, M-9, M-15, OPE-4). Електрофореграму спектрів ампліфікаційних фрагментів, одержаних за використання маркера ISSR2, представлено на рис. 1.

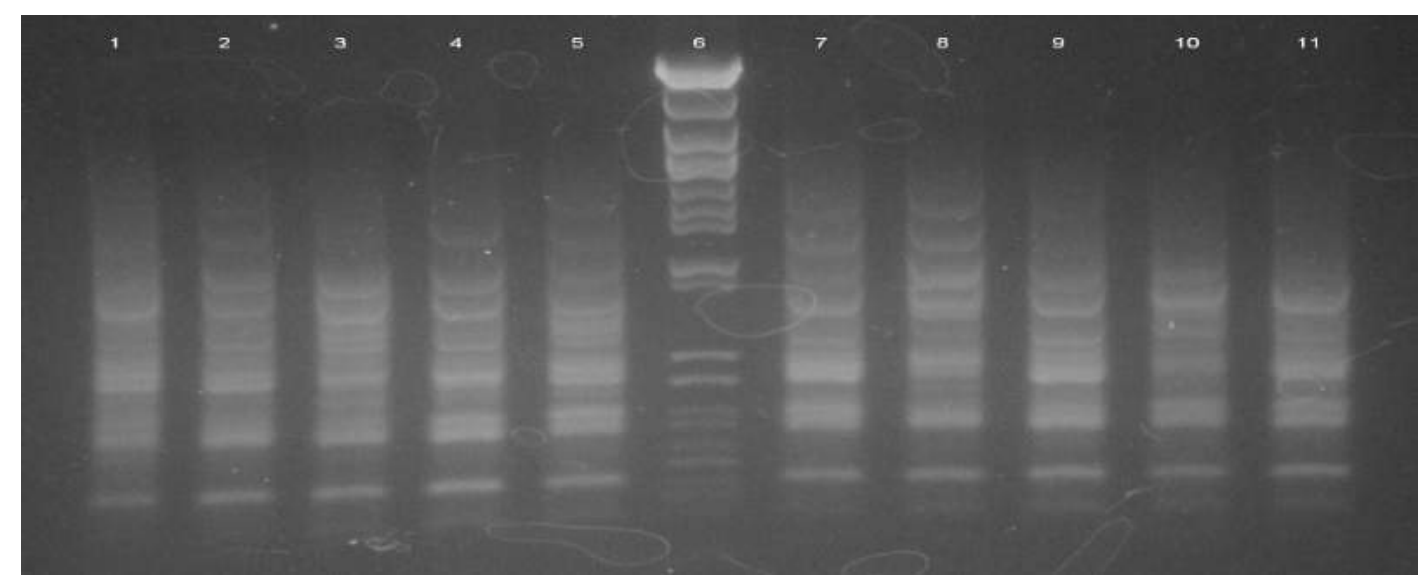

1-11-номери лунок; 1-5, 7-11-дослідні зразки, 6-маркер Вте18 I

Рис. 1 Електрофореграма спектра ампліфікаційних фрагментів, одержаних за допомогою маркера ISSR2

Аналіз результатів досліджень дав змогу виявити значний поліморфізм кожного з використаних ISSR-маркерів у піддослідній групі сріблясто-чорних лисиць. У кожному випадку (зразку) були наявні певні спектри ампліфікаційних фрагментів.

За кожним із маркерів визначено низку параметрів щодо оцінки рівня генетичної мінливості дослідної групи лисиць (табл. 1).

У цілому з 57 виявлених локусів за проаналізованими ISSR-маркерами лише один виявився мономорфним, тобто був присутній в усіх дослідних звірів. Розміри виявлених фрагментів знаходились в інтервалі від 150 п. н до 1650 п. н. Середня величина показника Р\% теж була високою і досягала майже 100 \%. При цьому за допомогою маркера ISSR2 виявлено на 13 фрагментів більше, порівняно 3 ISSR1.

Таблиия 1

Показники генетичної мінливості дослідної групи лисиць, оцінені за допомогою ISSR-маркерів

\begin{tabular}{|l|c|c|c|}
\hline \multicolumn{1}{|c|}{ Маркер } & TNB & NPB & P\% \\
\hline ISSR1 & 22 & 22 & 100 \\
\hline ISSR2 & 35 & 34 & 97,1 \\
\hline Загалом & 57 & 56 & - \\
\hline У середньому & 28,5 & 28 & 98,2 \\
\hline
\end{tabular}

Примітка. TNB - загальна кількість виявлених фрагментів; NPB - кількість виявлених поліморфних фрагментів і Р\% - відсоток виявлених поліморфних локусів 
За розподілом кількості локусів залежно від їх молекулярної маси для ISSR-маркерів одержано такі результати: для ISSR1 виявлено 8 фрагментів розміром до 500 п. н., 11 - від 500 до 1000 п. н., 3 - більших за 1000 п. н. У свою чергу для ISSR2 - відповідно 12, 15 і 8 локусів. Тоді як у середньому важких фрагментів установлено менше, ніж легких та середніх за розміром - відповідно 5,5 проти 10 та 13.

Електрофореграму спектрів ампліфікаційних фрагментів, одержаних за використання маркерів RAPD, подано на рис. 2.

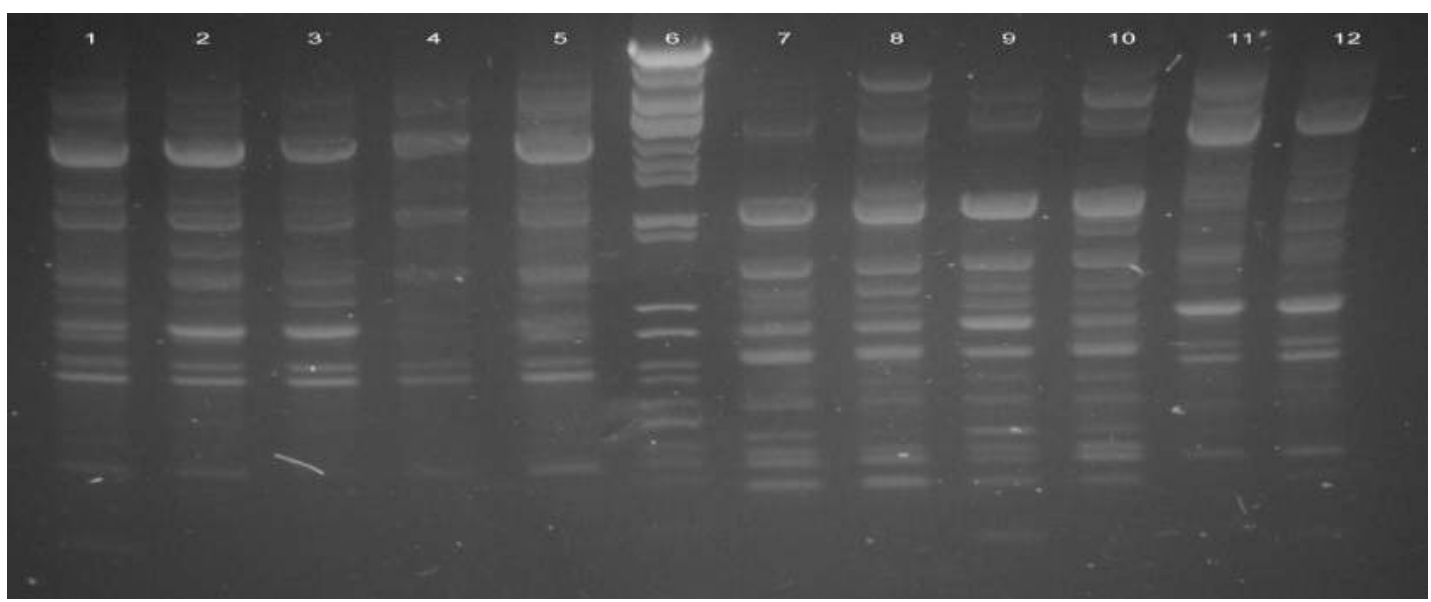

1 - 12 - номери лунок; 1-5, 7-12 - дослідні зразки, 6-маркер Вте18 I

Рис. 2 Електрофореграма спектра ампліфікаційних фрагментів, одержаних за допомогою маркера OPG-07

3'ясовано, що в переважній більшості проаналізованих зразків були виявлені специфічні спектри (набір локусів) майже для кожної особини піддослідної групи. Ампліфікаційні фрагменти за кожним з RAPD-маркерів, що використовували в дослідженні, характеризувалися різною кількістю та розмірами. Одержані дані свідчать про значний рівень поліморфізму.

На підставі аналізу одержаних спектрів ампліфікаційних фрагментів за RAPD-маркерами проведено оцінку показників генетичної різноманітності групи сріблясто-чорних лисиць (табл. 2).

Таблиия 2

Параметри оцінки генетичної різноманітності дослідної групи лисиць за використання RAPD-маркерів

\begin{tabular}{|l|c|c|c|}
\hline \multicolumn{1}{|c|}{ Маркер } & TNB & NPB & P\% \\
\hline OPG-04 & 29 & 29 & 100,0 \\
\hline OPG-07 & 34 & 34 & 100,0 \\
\hline OPG-17 & 22 & 20 & 90,9 \\
\hline M-9 & 30 & 27 & 90,0 \\
\hline M-15 & 20 & 19 & 95,0 \\
\hline OРE-4 & 23 & 19 & 82,6 \\
\hline Загалом & 158 & 148 & - \\
\hline У середньому & 26,3 & 24,7 & 93,9 \\
\hline
\end{tabular}

Примітка. TNB - загальна кількість виявлених фрагментів; NPB - кількість виявлених поліморфних фрагментів і Р\% - відсоток виявлених поліморфних локусів 
Найбільше число виявлених локусів з охоплених маркерів мав OPG-07 (34 фрагменти), найнижче - M-15 (20 фрагментів), тоді як за показником Р\%, котрий, крім того, вказує й на рівень розподільної здатності маркерів, найменшою величиною характеризувався OPE-4 (82,6 \%), найвищою - OPG-04 i OPG-07 (100 \%). Водночас розміри фрагментів варіювали від 150 до 3800 п. н.

У середньому кількість локусів на маркер для RAPD-маркерів виявилась нижчою за маркери ISSR на 2,2 фрагмента. Утім, у випадку RAPD загалом було виявлено майже втричі більше окремих локусів, ніж у випадку ISSR. Це пояснюється, у першу чергу, тим, що за структурою дослідні маркери, як правило, порізному представлені в геномі звірів; по-друге, маркерів RAPD було використано втричі більше, ніж ISSR. Поряд із цим слід відзначити, що для 4-х із 6-и маркерів RAPD установлено наявність мономорфних локусів у кількості від 1 до 4.

Середнє число мономорфних локусів виявилось також утричі більшим для RAPD-маркерів, порівняно з ISSR-маркерами. Тобто одержані результати свідчать про те, що чим більший набір маркерів використовують для аналізу генетичної мінливості, тим вищої розподільної здатності (тобто змоги диференціювання особин) можна досягнути у випадку використання підходів RAPD i ISSR.

За зіставлення одержаних власних результатів тестування та популяції російських лисиць виявлено, що піддослідна група характеризується майже вдвічі більшою кількістю локусів як у цілому, так і за окремими RAPD маркерами (75 локусів) [7]. Це може бути пов'язано з особливостями цього типу маркерів, які мають незначний рівень відтворюваності. Тому розбіжності між одержаними даними можна частково пояснити саме відмінностями умов різних лабораторій. У той же час для ISSR-маркерів загальне число виявлених локусів майже не різнилось (271 проти 264). Метод маркування генетичної мінливості за допомогою ISSR-маркерів свідчить про високу відтворюваність, що, ймовірно, зумовило менші відхилення результатів, порівняно з RAPD-маркерами.

Частина $з$ виявлених локусів характеризувалася невисокою частотою. Деякі локуси були унікальними, тобто мали місце лише в однієї особини, що може бути використано за аналізу спорідненості між звірами. Але було виявлено й декілька мономорфних локусів для різних маркерів (сумарно 10 фрагментів для RAPD, 1 - для ISSR), тобто таких, які притаманні всім особинам у групі. Деякі 3 них можуть виявитись видоспеціфічними, що, у випадку проведення додаткових досліджень, дасть змогу на генетичному рівні розрізняти між собою породи і види хутрових звірів.

У той же час, RAPD-аналіз може стати основою для конструювання інших типів маркерів (зокрема, SCAR-маркерів), котрі можуть бути пов'язаними з продуктивними ознаками хутрових звірів.

Висновки: 1. Конкретизовано параметри генетичної різноманітності групи сріблясто-чорних лисиць за ДНК-маркерами ISSR i RAPD.

2. Особливістю досліджуваної популяції сріблясто-чорних лисиць за ДНКмаркерами є досить значний рівень поліморфності, який для ISSR-маркерів коливався від 97,1 \% до 100,0 \% і для RAPD-маркерів - від 82,6 \% до 100 \%, що є свідченням високого рівня іiі біорізноманіття, незважаючи на розведення без „прилиття” крові.

3. Одержані нові дані щодо високого рівня генетичної мінливості групи сріблясто-чорних лисиць за використання полілокусних ДНК-маркерів обумовлюють необхідність оптимізації системного контролю селекційних заходів у стаді та забезпечують передумови для подальшої ефективної племінної роботи без ризику виникнення інбредної депресії. 


\section{Бібліографічний список}

1. Applying molecular tools for improving livestock performance: From DNA markers to next generation sequencing technologies / J. Sabir, M. Mutwakil, A. ElHanafy, A. Al-Hejin, M. Sadek, M. Abou-Alsoud, M. Qureshi, K. Saini, M. Ahmed // Journal of Food, Agriculture \& Environment. - 2014. - Vol. 12. - № 2. - P. 541-553.

2. Современные методы генетического контроля селекционных процессов и сертификация племенного материала в животноводстве: учеб. пособие / Н. А. Зиновьева, П. М. Кленовицкий, Е. А. Гладырь, А. А. Никишов. - Москва: РУДН, 2008. - 329 с.

3. Teacher A. G. F. Modern and ancient red fox (Vulpes vulpes) in Europe show an unusual lack of geographical and temporal structuring, and differing responses within the carnivores to historical climatic change / A. G. F. Teacher, J. A. Thomas, I. T. Barnes // BMC Evolutionary Biology. - 2011. - Vol. 11, № 1. - P. 214-222.

4. İbiş O. Phylogenetic Status of the Turkish Red Fox (Vulpes vulpes), based on Partial Sequences of the Mitochondrial Cytochrome b Gene / O. İbiş, C. Tez, S. Özcan // Vertebrate zoology. - 2014. - № 64 (2). - P. 273-284.

5. Stepniak E. Use of RAPD technique in evolution studies of four species in the family Canidae / E. Stepniak, M. Zagalska, M. Switonski // Journal of Applied Genetics. - 2002. - № 43(4). - P. 489-499.

6. Сулимова Г. Е. ДНК-маркеры в генетических исследованиях: типы маркеров, их свойства и области применения / Г. Е. Сулимова // Усnехи современной биологии. - 2004. - Т. 124, № 3. - С. 260-271.

7. Бекетов С. В. Роль изменчивости в повышении продуктивности пушных зверей семейств Canidae и Mustelidae : дисс. ... д-ра биол. наук : 06.02 .09 / Бекетов С. В. - Родники, 2015. - 335 с.

8. Genetics of behavior in the silver fox / A. V. Kukekova, S. V. Temnykh, J. L. Johnson, L. N., Trut, G. M. // Acland Mammalian Genome. - 2012. - Vol. 23, № 1-2. P. 164-177.

9. Red fox genome assembly identifies genomic regions associated with tame and aggressive behaviours / A. Kukekova, J. Johnson, X. Xiang, S. Feng, S. Liu, H. M. Rando, A. V. Kharlamova, Y. Herbeck, N. Serdyukova, Z. Xiong, V. Beklemischeva, K.-P. Koepfli, R. Gulevich, A. Vladimirova, J. Hekman, P. L. Perelman, A. Graphodatsky, S. O'Brien, X. Wang, A. Clark, G. Acland, L.Trut, G. Zhan // Nature Ecology \& Evolution. - 2018. - Vol. 2, № 9. - P. 1479-1491.

10. Genetics of interactive behavior in silver foxes (Vulpes vulpes) / R. M. Nelson, S. V. Temnykh, J. L. Johnson, A. V. Kharlamova, A.V. Vladimirova, R. G. Gulevich, D. V. Shepeleva, I. N. Oskina, G. M. Acland, L. C. Rönnegård, L. N. Trut, Ö. K. Carlborg, A. V. Kukekova // Behavior Genetics. - 2017. - № 47 (1), 88101.

\section{References}

1. Sabir, J., Mutwakil, M., El-Hanafy, A., Al-Hejin, A., Sadek, M., AbouAlsoud, M., Qureshi, M., Saini, K., \& Ahmed, M. (2014). Applying molecular tools for improving livestock performance: From DNA markers to next generation sequencing technologies. Journal of Food, Agriculture \& Environment, 12, 2, 541-553.

2. Zinov'eva, N. A., Klenovickij, P. M., Gladyr', E. A., \& Nikishov, A. A. (2008). Sovremennye metody geneticheskogo kontrolja selekcionnyh processov i sertifikacija plemennogo materiala $\mathrm{v}$ zhivotnovodstve [Modern methods of genetic control of breeding processes and certification of breeding material in animal husbandry]. Moskva : RUDN [in Russian]. 
3. Teacher, A. G. F., Thomas, J. A., \& Barnes, I. T. (2011). Modern and ancient red fox (Vulpes vulpes) in Europe show an unusual lack of geographical and temporal structuring, and differing responses within the carnivores to historical climatic change. BMC Evolutionary Biology, 11, 1, 214-222.

4. İbiş, O., Tez, C., \& Özcan, S. (2014). Phylogenetic Status of the Turkish Red Fox (Vulpes vulpes), based on Partial Sequences of the Mitochondrial Cytochrome $b$ Gene. Vertebrate zoology, 64 (2), 273-284.

5. Stepniak, E., Zagalska, M., \& Switonski, M. (2002). Use of RAPD technique in evolution studies of four species in the family Canidae. Journal of Applied Genetics, 43(4), 489-499.

6. Sulimova, G. E. (2004). DNK-markery v geneticheskih issledovanijah: tipy markerov, ih svojstva i oblasti primenenija [DNA markers in genetic research: types of markers, their properties and applications]. Uspehi sovremennoj biologii-Advances in Modern Biology, 124, 3, 260-271 [in Russian].

7. Beketov, S. V. (2015). Rol' izmenchivosti v povyshenii produktivnosti pushnyh zverej semejstv Sanidae i Mustelidae [The role of variability in increasing the productivity of fur-bearing animals of the families Canidae and Mustelidae]. Doctor's thesis. Rodniki [in Russian].

8. Kukekova, A. V., Temnykh, S. V., Johnson, J. L., Trut, L. N., \& Acland, G. M. (2012). Genetics of behavior in the silver fox. Mammalian Genome (Vol. 23), 1-2, 164-177.

9. Kukekova, A., Johnson, J., Xiang, X., Feng, S., Liu, S., \& Rando, H. M., Kharlamova, A. V., Herbeck, Y., Serdyukova, N., Xiong, Z., Beklemischeva, V., Koepfli, K.-P., Gulevich, R., Vladimirova, A., Hekman, J., Perelman, P. L., Graphodatsky, A., O’Brien, S., Wang, X., Clark, A., Acland, G., Trut, L., \& Zhan G. (2018). Red fox genome assembly identifies genomic regions associated with tame and aggressive behaviours. Nature Ecology \& Evolution (Vol. 2), 9, 1479-1491.

10. Nelson, R. M., Temnykh, S. V., Johnson, J. L., Kharlamova, A. V., Vladimirova, A.V., Gulevich, R. G., Shepeleva, D. V., Oskina, I. N., Acland, G. M., Rönnegård, L. C., Trut, L. N., Carlborg, Ö. K., \& Kukekova, A. V. (2017). Genetics of interactive behavior in silver foxes (Vulpes vulpes). Behavior Genetics, 47 (1), 88-101.

\section{ОЦЕНКА ГЕНЕТИЧЕСКОЙ ИЗМЕНЧИВОСТИ ГРУППЫ ЛИСИЦ ПО ДHК-MAPKEPAM ISSR И RAPD}

Петраш В. С., Корх О. В., Корх И. В., Шулика Л. В., Институт животноводства НААН.

Современные мировые научные достижения в области молекулярной генетики сосредоточили внимание исследователей на новых методах и подходах к генетическим исследованиям, которые базируются на непосредственном анализе ДНК, как основы наследственности и изменчивости животных, в том числе $и$ имеюших сельскохозяйственную иченность. Среди пушных зверей, содержашихся в неволе, лисица обыкновенная и серебристо-черная лисица, как ее меланистична форма, являются одними из перспективных объектов изучения с помощью молекулярно-генетических методов. На сегодняшний день в литературе накоплена значительная часть экспериментальных данных, раскрывающих сущчность и иирокое использование ДНК-маркеров для оченки генетического разнообразия различных сельскохозяйственных животных. Между тем в пушном звероводстве такие исследования начали реализовываться, по сравнению с другими отраслями животноводства, не так давно, а в оиенке полиморфизма ДНК - имеются лишь единичные сообщения. 
В рамках проведенных исследований проанализированы 54 головы лисии, от которых были отобраны образиы биологического материала (кусочки кожи с мехом) и получены спектры амплификачионных фрагментов по двум маркерам ISSR (ISSR1 u ISSR2) и шесть - RAPD (OPG-04 OPG-07 OPG-17, M-9, M-15, OPE4). Анализ полученных результатов позволил выявить значительный полиморфизм каждого из использованных ISSR-маркеров в подопытной группе лисии. В каждом случае (образие) имели место определенные спектры амплификационных фрагментов. Амплификачионные фрагменты по каждому из RAPD-маркеров, которые использовали в исследовании, характеризовались разным количеством и размерами, а в подавляющем большинстве проанализированных образиов также были обнаружены специфические спектры (набор локусов) почти для каждой особи подопытной группьы.

При использовании полилокусных ДНК-маркеров установлен высокий уровень геномной вариабельности опьтной группь лисии, что свидетельствует о достаточной степени ее популячионного биоразнообразия, несмотря на то, что она разводится в пределах замкнутой популяичи и не имеет , прилития” крови.

Ключевые слова: генетическая изменчивость, ДНК-маркеры, лисича, локуcы, полиморфизм, кусочки шкуры

\section{ASSESSMENT OF THE GENETIC VARIABILITY OF A GROUP OF FOXES WITH ISSR AND RAPD DNA MARKERS}

Petrash V. S., Korkh O. V., Korkh I. V., Shulika L. V., Institute of Animal Science of NAAS

Current global scientific advances in molecular genetics have focused researchers on new methods and approaches for genetic research based on direct DNA analysis, as the basis of animal heredity and variability, including those of agricultural value. Among the fur animals kept in captivity, the common fox and the silver-black fox, as its melanistic form, are one of the promising objects of study using molecular genetic methods. To date, much of the experimental data has been accumulated in the literature, revealing the nature and widespread use of DNA markers to assess the genetic diversity of different farm animals. Instead, such studies began to be implemented in furbreeding in comparison with other livestock industries not too long ago, and there were only isolated reports regarding the assessment of DNA polymorphism.

As part of the research, 54 fox were analyzed, from which samples of biological material (pieces of skin with fur) were taken, and spectra of amplification fragments were obtained according to two ISSR markers (ISSR1 and ISSR2) and six - RAPD (OPG-04, OPG-07, OPG-17, M-9, M-15, OPE -4). The analysis of the obtained results revealed the significant polymorphism of each of the ISSR markers used in the experimental group of foxes. In each case (sample) there were certain spectra of amplification fragments. The amplification fragments for each of the RAPD markers used in the study were characterized by different numbers and sizes, and in the vast majority of samples analyzed, specific spectra (set of loci) in almost each subject in the study group were also detected.

It should be noted that using polylocus DNA markers, a high level of genomic variability of the experimental group of foxes has been established, which indicates a sufficient degree of its population biodiversity, despite the fact that it breeds within a confined population and does not have a blood flow.

Key words: genetic variation, DNA markers, fox, loci, polymorphism, skin samples 